ALEKSANDER SZKAROWSKI

Koszalin University of Technology, Poland

Saint Petersburg State University of Architecture and Civil Engineering, Russia

e-mail: szkarowski@wp.pl
Manuscript submitted 2018.02.06 - revised 2018.05.23 initially accepted for publication 2018.08.08, published in December 2018

\title{
IMPROVING OF BOILER EFFICIENCY BY CONTROLLING THE HARMFUL SUBSTANCES CONCENTRATION IN THE COMBUSTION PRODUCTS
}

\section{POPRAWA SPRAWNOŚCI KOTKA POPRZEZ STEROWANIE STEŻENIEM SZKODLIWYCH SUBSTANCJI W PRODUKTACH SPALANIA}

DOI: $10.30540 /$ sae-2018-033

\begin{abstract}
Chemical carbon level control is considered to be one of the simplest, cheapest and the most effective methods of optimizing fuel combustion. Standardized balance boiler's tests show that maximum efficiency can be mentioned with highly noticeable chemical underburn responding to concentration of carbon monoxide 0.02-0.03\% vol. (200-300 ppm). In addition, nitrogen oxide, which originates in maximum temperature (with lack of underburn), is 35 times more toxic than carbon monoxide. It can be supposed that defining the permissible level of chemical underburn is a typical optimizing issue due to minimize the destination function. To simplify and unify the issue, ecological and economical fuel combustion criteria were proposed as well as general energy-ecology criterion, which is simultaneously the searched destination function. Results of such research on boilers have shown that optimum combustion operation takes place within carbon monoxide concentration of 234-379 $\mathrm{mg} / \mathrm{m}^{3}$, oxygen $4.11-4.24 \% \mathrm{vol}$. and air pressure $80-81 \mathrm{daPa}$.
\end{abstract}

Keywords: optimisation, energy-ecology criterion, carbon monoxide, boiler, flue gases

\section{Streszczenie}

Sterowanie poziomem niedopatu chemicznego uważa się za jedna z najprostszych, najtańszych $i$ wysokoefektywnych metod optymalizacji spalania paliwa. Standardowe bilansowe próby kotta pokazuja, że maksymalna jego sprawność notuje się przy wielce zauważalnym niedopale chemicznym odpowiadającym stężeniu CO na poziomie 0,02-0,03\% obj. (200-300 ppm). Ponadto tlenki azotu, które powstaja w maksymalnej temperaturze, czyli przy braku niedopału, sa substancjami około 35 razy bardziej toksycznymi niz tlenek węgla. Z tego wynika, że wyznaczenie dopuszczalnego poziomu niedopatu chemicznego stanowi typowe zagadnienie optymalizacyjne, majace na celu zminimalizowanie pewnej funkcji docelowej. Dla ujednolicenia tego problemu zostało zaproponowane ekologiczne i ekonomiczne kryterium spalania paliwa, jak również uogólnione kryterium energetyczno-ekologiczne będące poszukiwana funkcja docelowa. Jak pokazaly wyniki takich badań na kottach, optymalny tryb spalania znajduje się $w$ zakresie stężenia tlenku węgla w granicach 234-379 mg/m³ , tlenu 4,11-4,24\% obj. i ciśnienia powietrza 80-81 daPa.

Słowa kluczowe: optymalizacja, kryterium energo-ekologiczne, tlenki azotu, kocioł, paliwo gazowe

\section{INTRODUCTION}

Working for many years on theory and practice of effective and environment friendly fuel combustion, authors constantly promote the principle of energy - ecological optimisation [1]. Such approach means that optimum result of fuel combustion is qualified not only by direct efficiency of fuel consumption but

\section{WPROWADZENIE}

Zajmujący się od wielu lat zagadnieniami teorii i praktyki efektywnego i przyjaznego środowisku zużycia paliwa zespół autorski konsekwentnie promuje zasadę energetyczno-ekologicznej optymalizacji [1]. Takie podejście oznacza, iż optymalny wynik spalania paliwa wyznacza się nie tylko bezpośrednią sprawno- 
also by minimal damage made to people and natural environment $[2,14]$.

One of the simplest, cheapest and at the same time highly effective ways of such optimisation is the burning of fuel in a zone of controllable, remnant chemical underburn (RCU) [3, 9, 10]. This may sound paradoxically for many specialists. Most boiler operation specialists are used to obey the unquestionable rule: products of non complete fuel combustion, especially when burning gas fuel, shall not be present in flue gases. This publication is intended to evaluate this question from the energy-ecological optimisation point of view, that is optimisation regarding fuel savings as well as environment protection.

\section{IDEA OF CONTROLLABLE CHEMICAL UNDERBURN}

Usually concentration of incomplete combustion products in flue gases $\left(\mathrm{CO}, \mathrm{H}_{2}\right.$ and $\left.\mathrm{CH}_{4}\right)$ is considered as quantitative measure of chemical underburn. This factor determines a heat loss due to underburn (value $q_{3}$ in a heat balance of boiler unit). Traditional (for saving fuel) requirement of the total lack of chemical underburn products in flue gases is explained by eagerness for reducing $q_{3}$.

According to many years of boiler set up practice, in flue gases only traces of incomplete combustion products are permissible, which corresponds with CO concentration of $30 \div 50 \mathrm{mg} / \mathrm{m}^{3}$. In the branch publications it is recommended to arrange combustion with the air excess factor $(\alpha)$ higher about $0.03 \div 0.04$ than "critical" value (with some allowance for potential variation of factors that affect completeness of combustion). Just the appearance of underburn products [4] in flue gases is considered to be the critical value.

Results of extensive research made by authors' team evidence good reasoned possibility, both for economical and ecological reason, of increasing maximum permissible level of carbon monoxide concentration while burning natural gas in boilers equipped with blow-in turbulent burners.

Let's first consider incorrectness of the statement, which seems to be obviously true, that minimal underburn corresponds with maximum efficiency of fuel consumption in boilers [15]. Both, radiation and convection ways of heat receiving by waterwalls surrounding boilers furnace in a complicated way depends on many factors: shape, dimensions and luminosity of the flame, location of maximum ścią jego zużycia, lecz również minimalną szkodą wyrządzoną ludziom i środowisku naturalnemu [2, 14].

Jednym z najprostszych, najtańszych i jednocześnie wysokoefektywnych sposobów takiej optymalizacji jest spalanie paliwa w strefie regulowanego resztkowego niedopału chemicznego (RRNC) $[3,9,10]$. Dla wielu specjalistów od eksploatacji kotłów to może brzmieć paradoksalnie, przyzwyczajeni są przestrzegać niekwestionowaną regułę: w spalinach nie powinny występować produkty niezupełnego spalania paliwa, zwłaszcza przy spalaniu paliwa gazowego. Zadaniem tej publikacji jest spojrzenie na tę kwestię pod kątem pełnej energetyczno-ekologicznej optymalizacji, czyli optymalizacji zarówno pod względem oszczędzania paliwa, jak i ochrony środowiska.

\section{KONCEPCJA REGULOWANEGO NIEDOPALU CHEMICZNEGO}

Za ilościową miarę niedopału chemicznego zazwyczaj przyjmuje się sumaryczne stężenie produktów niezupełnego spalania w spalinach $\left(\mathrm{CO}, \mathrm{H}_{2} \mathrm{i} \mathrm{CH}_{4}\right)$. Ten wskaźnik wyznacza straty ciepła od niedopału (wartość $q_{3}$ w bilansie cieplnym agregatu kotłowego). Dążeniem do zmniejszenia $q_{3}$ wyjaśnia się tradycyjne (z racji oszczędzania paliwa) wymaganie całkowitego braku produktów niedopału chemicznego w spalinach.

Zgodnie z wieloletnią praktyką nastawiania kotłów, w spalinach dopuszczalne są wyłącznie „ślady” produktów niezupełnego spalania, co odpowiada stężeniu $\mathrm{CO}$ na poziomie $30 \div 50 \mathrm{mg} / \mathrm{m}^{3}$. W literaturze branżowej zaleca się zorganizowanie spalania ze współczynnikiem nadmiaru powietrza $(\alpha)$ o około $0,03 \div 0,04$ większym od wartości „krytycznej” (z pewnym zapasem na ewentualne wahania czynników wywierających wpływ na zupełność spalania). Przy czym za wartość „krytyczną” uważa się już sam fakt pojawienia się śladów produktów „niedopału” w spalinach [4].

Wyniki wykonanych przez zespół autorski obszernych badań świadczą o możliwości całkiem uzasadnionego, pod względem zarówno ekonomicznym, jak i ekologicznym, zwiększenia maksymalnie dopuszczalnego poziomu stężenia tlenku węgla przy spalaniu gazu ziemnego w kotłach wyposażonych w wirowe palniki nadmuchowe.

Zwróćmy najpierw uwagę na nieprawidłowość oczywistego, wydawałoby się, zdania, że minimalny niedopał odpowiada maksymalnej sprawności zużycia paliwa w kotłach [15]. Zarówno promieniowe, jak i konwekcyjne odbieranie ciepła przez powierzchnie ekranowe otaczające palenisko kotła w bardzo skomplikowany sposób zależy od wielu czynników: formy, 
temperature zones and the overall aerodynamics of the furnace space. Considerable influence of electricity consumption for driving fans and exhaust of flue gases on general energetic efficiency of a boiler shall also be kept in mind. Standard balance trials of a boiler show, that its maximum efficiency is noted at highly perceptible chemical underburn, corresponding with $\mathrm{CO}$ concentration in flue gases reaching $0.02 \div 0.03 \%$ vol. $(200 \div 300 \mathrm{ppm}$, or $250 \div 375 \mathrm{mg} / \mathrm{m}^{3}$ ).

Even more logical is "moving" the burning mode to the zone of chemical underburn due to minimal ecological detriment. It is enough to remind that nitrogen oxides $\left(\mathrm{NO}_{\mathrm{x}}\right)$ the most intensively generated in maximal temperature, that is at the lack of underburn, are substances about 35 times more toxic than carbon monoxide, because such is a relation of maximum permissible concentration of both these substances in inhaled air (respectively 0.085 and $3.0 \mathrm{mg} / \mathrm{m}^{3}$ ).

The above circumstances show clearly that determination of permissible level of chemical underburn is a typical optimisation issue that aims to minimize some target function. Complicated character if this issue consists in necessity of its individual solving in each case of set up the boiler, considering characteristics and details of all accompanying appliances of the complete furnace boiler unit [12].

\section{CRITERION FORM OF FUEL COMBUSTION OPTIMISATION ISSUE}

Different approaches to determination of the mentioned goal function are possible. Aiming to define the simplest optimum criterion of a furnace process following were applied:

- as the characteristic of combustion environment friendliness - coefficient of flue gases toxicity $G_{s p}$ (converted into $\mathrm{NO}_{x}$, according to I. Y. Sigal [5]);

- as the ration of the fuel consumption efficiency balance efficiency of the boiler unit (gross) $\eta_{b r}[16]$. At the same time toxicity coefficient was determined on the basis of $\mathrm{CO}, \mathrm{NO}_{x}$ and 3.4-benzopyrone concentration in flue gases, while efficiency according to standard method of boiler balance tests $[4,13]$.

Aiming to unify these coefficients following equations of ecological $\left(A_{1}\right)$ and economical $\left(A_{2}\right)$ criteria representing relative change of above selected characteristic parameters: rozmiarów i świecenia się płomienia, położenia strefy maksymalnych temperatur oraz całokształtu aerodynamiki przestrzeni paleniska. Nie można zapomnieć też o istotnym wpływie zużycia energii elektrycznej na napęd wentylatorów i wyciągów spalin na ogólną sprawność energetyczną kotła. Standardowe bilansowe próby kotła pokazują, że maksymalną jego sprawność notuje się przy wielce zauważalnym niedopale chemicznym, odpowiadającym stężeniu $\mathrm{CO}$ w spalinach na poziomie $0,02 \div 0,03 \%$ obj. $\left(200 \div 300\right.$ ppm, lub $\left.250 \div 375 \mathrm{mg} / \mathrm{m}^{3}\right)$.

Jeszcze bardziej logiczne jest „przesunięcie” trybu spalania ku strefie niedopału chemicznego ze względu na minimalny uszczerbek ekologiczny. Wystarczy przypomnieć, że tlenki azotu $\left(\mathrm{NO}_{\mathrm{x}}\right)$ najbardziej intensywnie powstające w maksymalnej temperaturze, czyli przy braku niedopału, są to substancje około 35 razy bardziej toksyczne, niż tlenek węgla, taką, bowiem wartość stanowi stosunek maksymalnie dopuszczalnych koncentracji tych substancji we wdychanym powietrzu (odpowiednio 0,085 i 3,0 mg/ $/ \mathrm{m}^{3}$ ).

$\mathrm{Z}$ powyższych przesłanek wyraźnie wynika, iż wyznaczanie dopuszczalnego poziomu niedopału chemicznego stanowi typowe zagadnienie optymalizacyjne, mające na celu zminimalizowanie pewnej funkcji docelowej. Skomplikowany charakter tego zagadnienia polega na konieczności jego indywidualnego rozwiązania w każdym konkretnym przypadku nastawiania kotła, z uwzględnieniem charakterystyk i szczegółów wszystkich składowych urządzeń całego zespołu kotłowo-paleniskowego [12]

\section{KRYTERIALNA FORMA ZAGADNIENIA OPTYMALIZACJI SPALANIA PALIWA}

Możliwe są rozmaite podejścia do określenia wspomnianej funkcji docelowej. W celu zdefiniowania najprostszego kryterium optymalności procesu paleniskowego przyjęto:

- jako charakterystykę ekologiczności spalania wskaźnik toksyczności spalin $G_{s p}$ (w przeliczeniu na $\mathrm{NO}_{x}$, według I. Ja. Sigała [5]);

- jako wskaźnik sprawności zużycia paliwa - bilansową sprawność agregatu kotłowego (brutto) $\eta_{b r}[16]$.

Przy czym wskaźnik toksyczności określano na podstawie stężenia $\mathrm{CO}, \mathrm{NO}_{\mathrm{x}}$ i 3,4-benzpirena w spalinach, a sprawność - zgodnie ze standardową metodą prób bilansowych kotła $[4,13]$.

Aby ujednolicić wskaźniki zaproponowano następujące wzory kryteriów ekologiczności $\left(A_{1}\right)$ i ekonomiczności $\left(A_{2}\right)$, odzwierciedlających względną zmianę wybranych wyżej charakterystycznych parametrów: 


$$
A_{1}=\frac{G_{s p}-G_{s p}^{\min }}{G_{s p}^{\max }-G_{s p}^{\min }} ; A_{2}=\frac{\eta_{b r}^{\max }-\eta_{b r}}{\eta_{b r}^{\max }-\eta_{b r}^{\min }}
$$

where:

$G_{s p}, \eta_{b r}$ - current values of parameters, according to which, ecologicalness and efficiency of combustion process are evaluated;

$G_{s p}^{\min }, G_{s p}^{\max }, \eta_{b r}^{\min }, \eta_{b r}^{\max }-$ minimal and maximum of possible (registered during all trials) values of respective factors in considered variation range of coefficient values.

It was logical to apply the sum of above both criteria as generalised energy - ecological criterion $(A)$, which is the target function, looked for:

$$
A=A_{1}+A_{2}
$$

Equation (1) shows, that values of criteria $A_{1}$ and $A_{2}$ are within the range from 0.0 (the best possible combustion mode) up to 1.0 (the worst recorded mode). Value of criterion $A$, according to equation (2) may vary from 0.0 (when energetic and ecologic optimum are in line) up to 2.0 ( the most unfavourable case when the worst modes of boiler operation, both regarding energy saving as well as environment protection, are in line).

\section{TEST CONDITIONS AND THE STUDY METHODOLOGY}

With use of the above defined idea of general energy - ecologic criterion a range of research works has been done, allowing to submit a proposition on reasoned increase of permissible level of chemical underburn when burning gas fuel in boilers. The main part of the test was carried out in real operation conditions on vertical pipe steam boilers with turbulent burners of different types, providing different rate of gas and air streams mixing in the furnace space. Measurements were taken according to standard method described in details in [4]. Determination of $\mathrm{CO}, \mathrm{O}_{2}, \mathrm{NO}_{2}$ concentration and temperature of flue gases was done by mean of flue gases analyzer Optima-7. Determination of 3.4-benzopyrone $\left(\mathrm{C}_{20} \mathrm{H}_{12}\right)$ in flue gases was done with simplified method $[6,7]$.

To look for the above mentioned optimum, first maximum and minimum values of $G_{s p}$ and $\eta_{b r}$ were determined at successively changed values of non controllable factors. Then their current values were determined at given rate of controllable parameter (that was a volume of air stream blown to burners) and respective values of $A_{1}, A_{2}$ i $A$ criteria were calculated.

$$
A_{1}=\frac{G_{s p}-G_{s p}^{\min }}{G_{s p}^{\max }-G_{s p}^{\min }} ; A_{2}=\frac{\eta_{b r}^{\max }-\eta_{b r}}{\eta_{b r}^{\max }-\eta_{b r}^{\min }}
$$

gdzie:

$G_{s p}, \eta_{b r}$ - bieżące wartości parametrów, według których ocenia się ekologiczność i sprawność procesu spalania;

$G_{s p}^{\min }, G_{s p}^{\max }, \eta_{b r}^{\min }, \eta_{b r}^{\max }-$ minimalne i maksymalne z możliwych (odnotowanych podczas wszystkich prób) wartości odpowiednich parametrów w rozpatrywanym przedziale zmiany przestrzeni czynnikowej.

Jako uogólnione kryterium energetyczno-ekologiczne $(A)$, będące poszukiwaną funkcją docelową, logicznie było przyjąć sumę dwóch powyższych kryteriów:

$$
A=A_{1}+A_{2}
$$

Ze wzorów (1) wynika, że wartości kryteriów $A_{1}$ i $A_{2}$ znajdują się w przedziale od 0,0 (najlepszy $\mathrm{z}$ możliwych tryb spalania) do 1,0 (najgorszy odnotowany wariant). Kryterium $A$, zgodnie ze wzorem (2), może przyjmować wartości od 0,0 (gdy optima energetyczne i ekologiczne pokrywają się) do 2,0 (skrajnie niekorzystny przypadek, gdy pokrywają się najgorsze tryby pracy kotła pod względem zarówno oszczędzania energii, jak i ochrony środowiska).

\section{WARUNKI EKSPERYMENTU I METODYKA BADAŃ}

Z wykorzystaniem wyprowadzanego wyżej pojęcia uogólnionego kryterium energetyczno-ekologicznego wykonano szereg prac doświadczalnych, które pozwoliły zdefiniować tezę o uzasadnionym podwyższeniu dopuszczalnego poziomu niedopału chemicznego przy spalaniu paliwa gazowego w kotłach. Główna część eksperymentów odbyła się w rzeczywistych warunkach eksploatacji na kotłach parowych pionowo-rurowych z palnikami wirowymi różnych typów, zapewniającymi różną intensywność zmieszania strumieni gazu i powietrza w przestrzeni paleniska. Pomiary wykonywano według standardowych metod opisanych dokładnie w [4]. Określenie stężenia $\mathrm{CO}, \mathrm{O}_{2}, \mathrm{NO}_{2}$ i temperatury spalin wykonywano za pomocą analizatora spalin Optima-7. Określenie koncentracji 3,4-benzpirena $\left(\mathrm{C}_{20} \mathrm{H}_{12}\right)$ w spalinach wykonywano przez uproszczoną metodę $[6,7]$.

W celu poszukiwania wyżej wymienionego optimum najpierw ustalano maksymalne i minimalne wartości $G_{s p}$ i $\eta_{b r}$ przy kolejno zmieniających się wartościach nieregulowanych czynników. Potem określano ich bieżące wartości przy danym znaczeniu regulowanego parametru (jakim był strumień objętości powietrza doprowadzanego do palników) i obliczano odpowiednie wartości kryteriów $A_{1}, A_{2}$ i $A$. 


\section{ANALYSIS OF RESULTS}

Figures $1 \div 3$ presents data typical for research carried out, representing relation of selected efficiency and ecologicalness coefficients of the boiler operation and $\mathrm{CO}, \mathrm{O}_{2}$ concentration in flue gases and air pressure [11]. Data was obtained on steam boiler with rated output $20 \mathrm{t} / \mathrm{h}$ with two double-flow turbulent burners GMG-m with rated output 8.1 MW each, located in front of the boiler in one vertical axis.
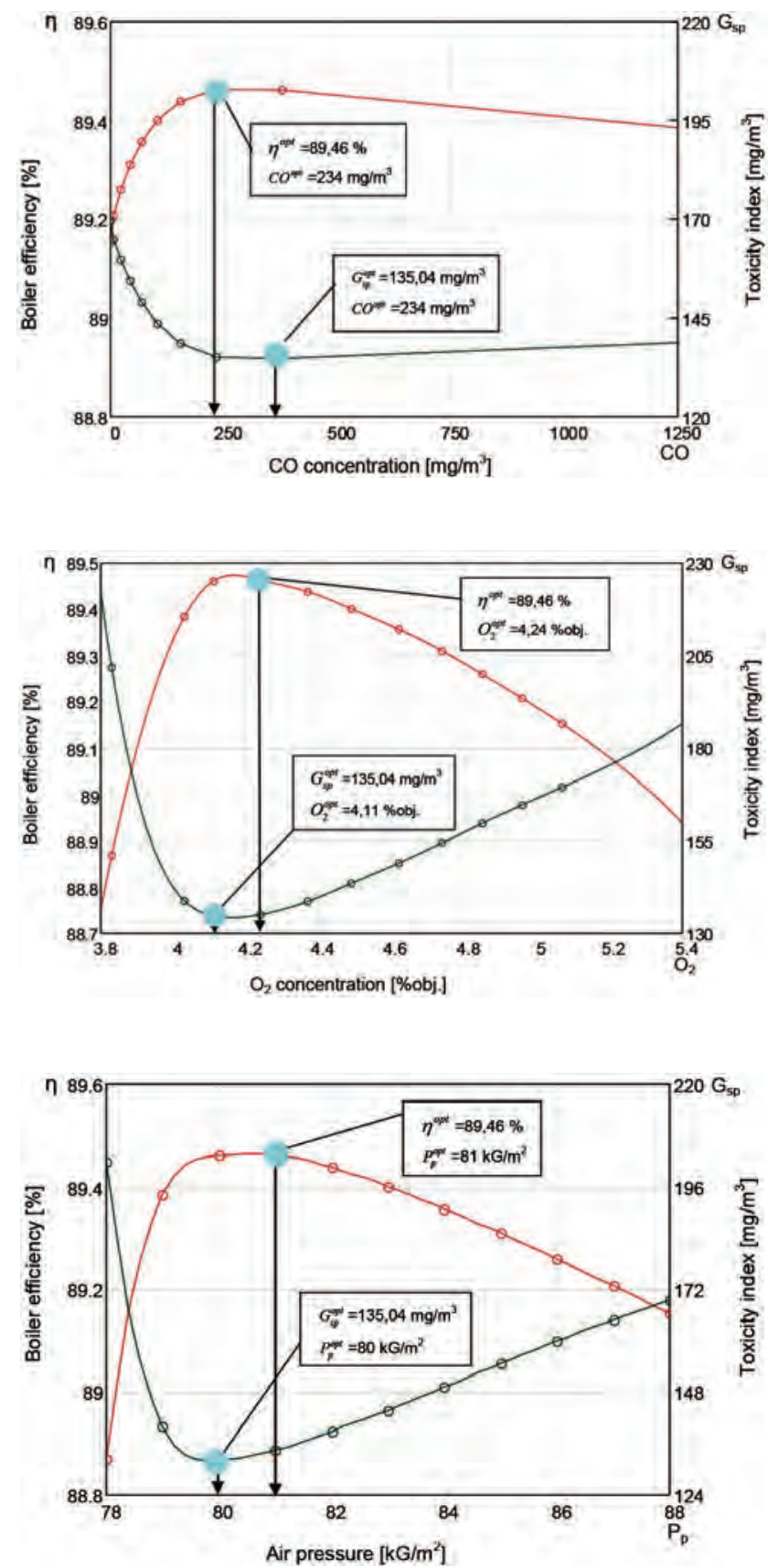

\section{ANALIZA WYNIKÓW BADAŃ}

Na rysunkach $1 \div 3$ przedstawiono typowe dla wykonanych badań dane ilustrujące zależność wybranych wskaźników efektywności i ekologiczności pracy kotła od koncentracji $\mathrm{CO}, \mathrm{O}_{2}$ w spalinach [11]. Dane otrzymano na kotle parowym o nominalnej wydajności $20 \mathrm{t} / \mathrm{h} \mathrm{z}$ dwoma dwuprzepływowymi wirowymi palnikami o nominalnej mocy 8,1 MW każdy, usytuowanymi z frontu kotła na jednej osi pionowej.

Fig. 1. Boiler efficiency (red line) and combustion products toxicity index (green line) depending on the flue gas $\mathrm{CO}$ concentration for industrial burner GMG-m and gas pressure $250 \mathrm{daPa}$

Rys. 1. Sprawność kotta (linia czerwona) i toksyczność spalin (linia zielona) w zależności od stężenia tlenku węgla w spalinach dla palnika typu GMG-m przy ciśnieniu gazu $250 \mathrm{daPa}$

Fig. 2. Boiler efficiency (red line) and combustion products toxicity index (green line) depending on the flue gas $O_{2}$ concentration for industrial burner GMG-m and gas pressure $250 \mathrm{daPa}$

Rys. 2. Sprawność kotta (linia czerwona) i toksyczność spalin (linia zielona) $w$ zależności od stężenia tlenu w spalinach dla palnika typu GMG-m przy ciśnieniu gazu $250 \mathrm{daPa}$

Fig. 3. Boiler efficiency (red line) and combustion products toxicity index (green line) depending on the air pressure for industrial burner GMG-m and gas pressure $250 \mathrm{daPa}$ Rys. 3. Sprawność kotta (linia czerwona) i toksyczność spalin (linia zielona) w zależności od ciśnienia powietrza w spalinach dla palnika typu GMG-m przy ciśnieniu gazu $250 \mathrm{daPa}$ 
Maximum value $\eta_{b r}$ of the boiler unit corresponds with minimal sum of its energetic loss depending on the volume of air flow:

- stack loss,

- loss due to chemical underburn,

- electrical energy requirement for driving fan and flue gases exhaust.

It appears from the presented diagrams that optimum combustion modes are within the carbon dioxide concentration range of $200 \div 400 \mathrm{mg} / \mathrm{m}^{3}$, oxygen concentration $4 \div 4.3 \%$ vol. and air pressure $80 \div 81 \mathrm{daPa}$. While approaching the zone of complete combustion results with noticeable lowering of the boiler efficiency and considerable worsening of ecologic combustion coefficients.

Figures $4 \div 6$ illustrates results of the same data processing according to above presented method of energy saving and ecologicalness of fuel consumption. As it appears from diagrams, optimum of respective criteria $\boldsymbol{A}_{1}$ and $\boldsymbol{A}_{2}$, as well as minimum value of generalised criterion $A$ are within quite narrow range of $\mathrm{CO}$ concentration variation, that is $230 \div 380 \mathrm{mg} /$ $\mathrm{m}^{3}$, oxygen $4.11 \div 4.24 \%$ vol, air pressure $80 \div 81$ $\mathrm{daPa}$, what in turn corresponds with range of air excess coefficient variation of about 0.01 .
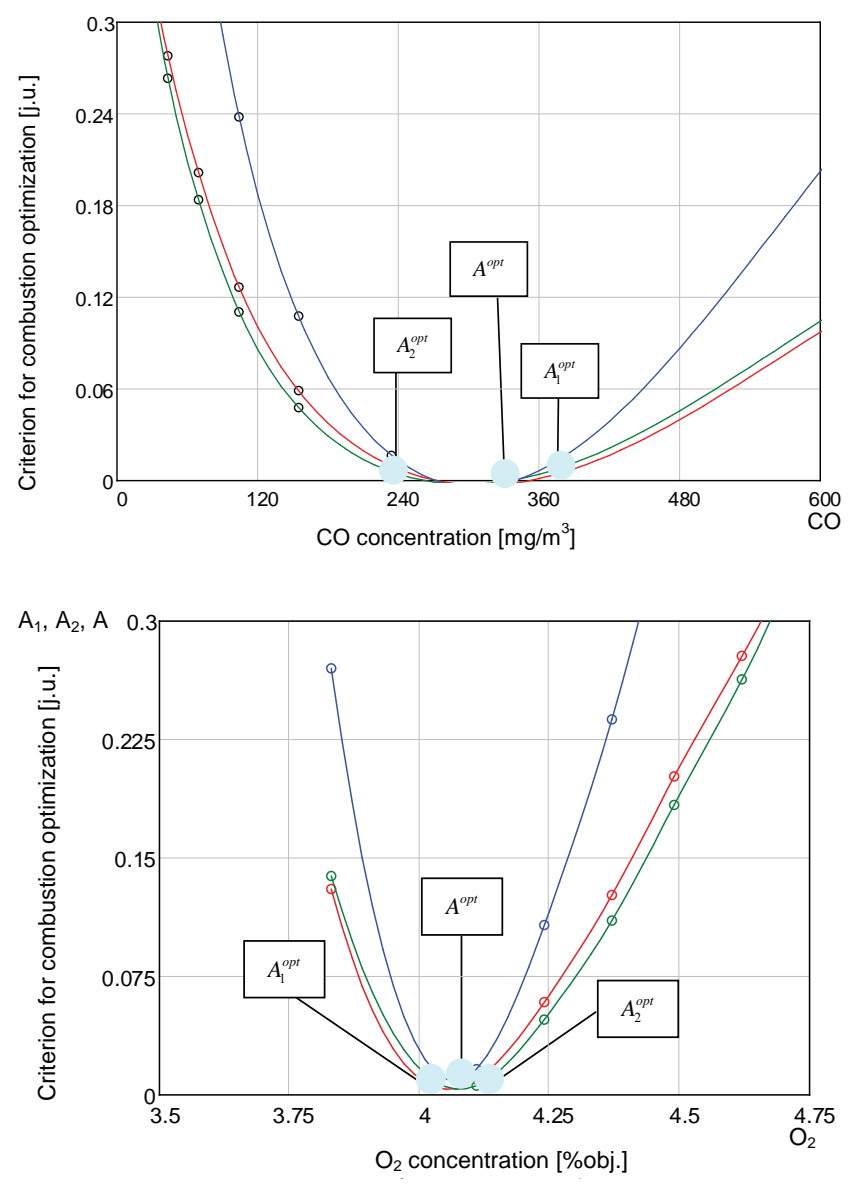

Maksymalna wartość $\eta_{b r}$ agregatu kotłowego odpowiada minimum sumy jego strat energetycznych zależnych od strumienia objętości powietrza:

- strat ciepła spalinowych,

- strat od niedopału chemicznego,

- zapotrzebowania energii elektrycznej do napędzania wentylatora i wyciągu spalin.

Z przedstawionych wykresów wynika, że optymalne tryby spalania znajdują się w zakresie stężenia tlenku węgla $200 \div 400 \mathrm{mg} / \mathrm{m}^{3}$, tlenu $4 \div 4,3 \%$ obj. i ciśnienia powietrza $80 \div 81 \mathrm{daPa}$. Zaś zbliżenie się ku strefie z zupełnym spalaniem skutkuje zauważalnym obniżeniem sprawności kotła i istotnym pogorszeniem ekologicznych wskaźników spalania.

Rysunki 4 $\div 6$ ilustruje wyniki obróbki tych samych danych według przedstawionej wyżej metody kryteriów energooszczędności i ekologiczności zużycia paliwa. Jak widać z wykresów, optima poszczególnych kryteriów $\boldsymbol{A}_{1}$ i $\boldsymbol{A}_{2}$ oraz minimalna wartość uogólnionego kryterium $A$ znajdują się w dość wąskim przedziale zmiany koncentracji $\mathrm{CO}$, mianowicie $230 \div 380 \mathrm{mg} / \mathrm{m}^{3}$, tlenu $4,11 \div 4,24 \%$ obj., ciśnienia powietrza $80 \div 81 \mathrm{daPa}$, co z kolei odpowiada przedziałowi zmiany współczynnika nadmiaru powietrza ok. 0,01 .

Fig. 4. Search for the optimum CO concentration by the criterial method (condition for experiment the same as for Figure 1)

Rys. 4. Kryteria optymalności spalania w zależności od stężenia tlenku węgla w spalinach (warunki eksperymentu zgodne z rysunkiem 1)

Fig. 5. Search for the optimum $\mathrm{O}_{2}$ concentration by the criterial method (condition for experiment the same as for Figure 2)

Rys. 5. Kryteria optymalności spalania w zależności od stężenia tlenu w spalinach (warunki eksperymentu zgodne z rysunkiem 2) 


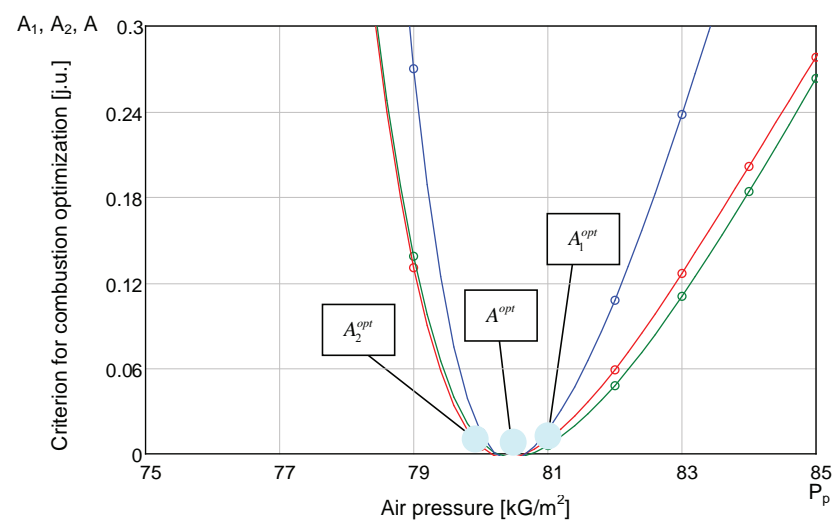

Similar data, slightly differing in details, was obtained for other types of boilers and different burners. It shall be noted, that with increase of $\mathrm{CO}$ concentration from optimum, value of $A$ criterion, as well as value of original factors $\left(G_{s p}\right.$ i $\left.\eta_{b r}\right)$ on the beginning change slightly. This gave possibility to consider concentration of $\mathrm{CO}$ in flue gases on the level of $500 \div 600 \mathrm{mg} / \mathrm{m}^{3}$ as „critical”. In turn the "protective" margin of air excess coefficient value, recommended during set up boilers, equals $0.02 \div 0.03$ of the critical value, what guarantees continuous operation of the boiler in the mode close to energy-ecological optimum.

However the margin mentioned shall be applied only for boilers equipped with traditional automatic units, still quite often operated in Poland.

The most positive result of the controllable method of remnant chemical underburn is achieved with use of numerical systems of fuel combustion quality control [8], which operate on the basis of "current" results of the gas analysis. In this case there is no need to use idea of "critical" concentration of CO or applying "protective" margin of air excess. This type of units in a continuous way maintain mode of combustion and the whole boiler operation in the zone close to optimum, while optimum itself is corrected depending on calorific value of the fuel, technical condition of the boiler, climatic conditions and other affecting factors.

\section{CONCLUSIONS}

1. Complete lack of chemical underburn products in flue gases does not indicate high efficiency and ecologicalness of fuel combustion in boiler units. In most cases maximum efficiency as well as minimal toxicity of flue gases, in practice of set up boilers, is achieved at the $\mathrm{CO}$ concentration in flue gases within the range $200 \div 400 \mathrm{mg} / \mathrm{m}^{3}$.
Fig. 6. Search for the optimum air pressure by the criterial method (condition for experiment the same as for Figure 3) Rys. 6. Kryteria optymalności spalania $w$ zależności od ciśnienia powietrza $w$ spalinach (warunki eksperymentu zgodne z rysunkiem 3)

Podobne dane, nieznacznie różniące się w szczegółach, otrzymano dla innych typów kotłów i różnych palników. Należy zauważyć, że przy wzroście stężenia CO od położenia optimum wartość kryterium $A$, jak też samych pierwotnych wskaźników $\left(G_{s p}\right.$ i $\left.\eta_{b r}\right)$ na początku zmienia się nieznacznie. To dało możliwość uznania za „krytyczną” koncentrację CO w spalinach na poziomie $500 \div 600 \mathrm{mg} / \mathrm{m}^{3}$. Z kolei ,asekuracyjny” zapas wartości współczynnika nadmiaru powietrza, zalecany podczas nastawiania kotłów, wynosi $0,02 \div 0,03$ wartości krytycznej, co gwarantuje stałą pracę kotła w trybie zbliżonym do optimum energetyczno-ekologicznego.

Jednak wspomniany zapas stosować należy tylko na kotłach wyposażonych w tradycyjne, jeszcze dość często spotykane w kraju, układy automatyki.

Największy efekt stosowania metody regulowanego resztkowego niedopału chemicznego osiągany jest przy wykorzystaniu mikroprocesorowych systemów sterowania jakością spalania paliwa [8], których praca opiera się o wyniki analizy gazowej na „bieżąco”. W tym przypadku nie ma potrzeby stosowania pojęcia „krytycznego” stężenia CO czy „asekuracyjnego” zapasu nadmiaru powietrza. Układy tego typu w sposób ciągły utrzymują tryb spalania i całej pracy kotła w strefie maksymalnie bliskiej optimum, przy czym same optimum korygowane jest w zależności od kaloryczności paliwa stanu technicznego kotła, warunków klimatycznych i innych czynników wpływu.

\section{WNIOSKI}

1. Całkowity brak produktów niedopału chemicznego w spalinach bynajmniej nie świadczy o wysokiej sprawności i ekologiczności spalania paliwa w agregatach kotłowych. Maksimum sprawności, jak również minimalną toksyczność spalin w większości przypadków w praktyce nastawiania kotłów notuję się przy stężeniu $\mathrm{CO}$ w spalinach na poziomie $200 \div 400 \mathrm{mg} / \mathrm{m}^{3}$. 
2. The method of fuel combustion with controllable remnant chemical underburn (RCU) on such level provides continuous energy-ecological result. At the same time suggested range of RCU is very close to all traditional blow-in turbulent burners.

3. When setting boilers up, recommended concentration of $\mathrm{CO}$ equalling $500 \mathrm{mg} / \mathrm{m}^{3}$, above which signs of non stable resonant burning appear, may be considered to as "critical". In these conditions concentration of $\mathrm{H}_{2}, \mathrm{CH}_{4}$, 3,4-benzopyren, formaldehyde as well as other products of incomplete combustion may considerably increase.

4. When setting up boilers with traditional automatic system (without continuous analysis of flue gases) it is recommended that the margin of the air excess coefficient, compared to "critical" mode, equals on average $0.02 \div 0.03$.

5 . The best result of RCU method application is achieved if boiler is equipped with system of automatic control fuel - air relation on the basis of continuous analysis of flue gases content.
2. Metoda spalania paliwa $\mathrm{z}$ regulowanym resztkowym niedopałem chemicznym (RRNC) na takim poziomie daje stały eksploatacyjny efekt energetyczno-ekologiczny. Sugerowany przedział RRNC jest bardzo zbliżony dla wszystkich tradycyjnych wirowych palników nadmuchowych.

3. Jako „krytyczna” koncentracja CO przy wykonaniu prac nastawiania kotłów zalecana może być wartość $500 \mathrm{mg} / \mathrm{m}^{3}$, powyżej której obserwuje się oznaki niestałego spalania pulsacyjnego. W tych warunkach może znacznie wzrastać koncentracja $\mathrm{H}_{2}, \mathrm{CH}_{4}, 3$,4-benzpirena, formaldehydu i innych produktów niezupełnego spalania.

4. Podczas nastawiania kotłów z tradycyjnym układem automatyki (bez stałej analizy spalin) zalecana eksploatacyjna nadwyżka współczynnika nadmiaru powietrza, w porównaniu z trybem „krytycznym", wynosi średnio $0,02 \div 0,03$.

5. Największy efekt stosowania metody RRNC osiągany jest przy wyposażeniu kotłów w układy automatycznej regulacji stosunku paliwo-powietrze na podstawie wyników stałej analizy składu spalin.

\section{REFERENCES}

[1] Szkarowski A.: Estimation of modern tendencies In Environment Pollution. Annual Set The Environment Protection. Vol. 5, 2003, pp. 67-78.

[2] Novikov O., Artamonov D., Shkarowski A.: Energy and ecological optimization of fuel combustion in boiler and furnace via regulation of fuel-air ratio. Energy Power Engineering nr 5, 2000, pp. 57-60.

[3] Baryshev V., Beloselskiy B., Zenkevich L., Shpolivskaya L.: Decrease of nitrogen oxides emission via adjustable residual chemical underburn. Heating Engineering 4, 1996.

[4] Trembovla V., Finger E., Avdeyeva A.: Thermal Tests of Boilers. Moscow: Energoatomizdat, 1991.

[5] Sigal I.: Environment Protection at Fuel Burning. Leningrad: Nedra, 1988.

[6] Bezrukih V.: Choice of Optimum Parameters of a Gas-air Mix in Burners of Low Power Boilers for Fuel saving and Reduction Harmful Substances Emission. The thesis for a doctor's degree. Leningrad: LISI, 1988.

[7] Komina G.: Research of Products of Hydrocarbon Gases burning and Reduction Harmful Emissions. The thesis for a doctor's degree. Leningrad, 1971.

[8] Szkarowski A., Nowikow O., Okatjew A., Kociergin M.: The Intellectual System of a Combustion Quality Control. In Proceedings of IV National Polish Scientific Conference on Complex and Detailed Problems of Environmental Engineering. Koszalin- Ustronie Morskie, Poland, 2003: 117-126.

[9] Szkarowski A., Janta-Lipińska S.: Automatic Control of Burning Quality of Solid Fuel in Industrial Heating Boilers. Annual Set The Environment Protection. Vol. 11, 2009, s. 241-255.

[10] Szkarowski A., Janta-Lipińska S.: Modeling of Optimum Burning of Fuel in Industrial Heating Boilers. Annual Set The Environment Protection. Vol. 13, 2011, pp. 511-524.

[11] Szkarowski A., Janta-Lipińska S.: Examination of boiler operation energy-ecological indicators during fuel burning with controlled residual chemical underburn. Annual Set The Environment Protection. Vol. 15, 2013, pp. 981-995.

[12] Szkarowski, A., Janta-Lipińska, S. Experimental Research Vs. Accuracy of the Elaborated Model. Annual Set The Environment Protection. Vol. 17, 2015, pp. 576-584.

[13] Szkarowski, A., Janta-Lipińska, S., Gawin, R.: Reducing Emissions of Nitrogen Oxides from DKVR Boilers. Annual Set The Environment Protection. Vol. 18, 2016, pp. 565-578.

[14] Pavlenko, A., Szarowski, A., Janta-Lipińska, S.: Research on Burning of Water Black Oil Emulsions. Annual Set The Environment Protection. Vol. 16, 2014, pp. 376-385. 
[15] Szyszlak-Bargłowicz J., Zając G., Słowik T.: Badanie emisji wybranych zanieczyszczeń gazowych podczas spalania peletów z agro biomasy w kotle małej mocy. Annual Set The Environment Protection. Vol. 19, 2017, pp. 715-730.

[16] Fijałkowska D., Styszko L.: Ciepło spalania biomasy wierzbowej. Annual Set The Environment Protection. Vol. 13, 2011, pp. 875-890.

Acknowledgments:

The work was financed by Koszalin University of Technology

\section{Podziękowania:}

Praca była finansowana przez Politechnikę Koszalińska 